\title{
The Externalization of European Borders: The Other Face of Coloniality Turkey as a Case Study
}

\author{
By Hafsa Afailal \\ Maria Fernandez
}

Turkey's border controls were not a priority as they have been for the Schengen Europe, but the negotiations to access the European Union and the recent agreement on tighter migration controls transformed this open behaviour into a more conservative one, through the externalization process of the European borders. This article focuses on how the new organisational models of power relations can be explained through the theory of the coloniality of power, marked by a Eurocentric form of imposition. The construction of the externalised European borders represents a new form of coloniality, classifying the population (migrant vs. EU citizen) and the countries (EU members vs. countries where control has been externalised to) according to the level of threat they represent for the EU. As a result of these dynamics, Turkey has a new migration policy that is quite selective deciding who might or might not enter the fortress, replicating this way the difficulties of navigating the European migration policy, despite the fact that the country is not a member of the European Union.

Keywords: coloniality of power, diversity, European border externalisation, Turkey.

\section{Introduction}

The Mediterranean region cannot be studied or thought without analysing human mobility. Throughout history, the Mediterranean has constituted a space for the movements of different groups and cultures. Nowadays, the migratory context of the Middle East and North Africa (MENA) region, specifically, has changed substantially in 2011 with the uprisings and the transformations they brought to the political, social and economic landscapes of many countries in the area. Together with the existing protracted conflicts like the Israeli occupation of the Palestine or the ongoing unstable situation in places like Iraq, the region witnessed major displacements.

This paper is part of a research initiated after the signature of the agreement between Turkey and the European Union (EU 2014) "on the readmission of persons residing without authorisation" as the text indicates, to observe the development of its implementation, explaining why conclusions in this article are still subject to change, or evolve in the coming period.

The Internal Displacement Monitoring Centre (IDMC) reported (2011: 72) that, "the internal displacement which resulted in Libya, Syria and Yemen contributed to the tripling of the number of IDP in the region between 2001 and the end of 2011". Around 840,000 people were newly displaced in the

${ }^{*} \mathrm{PhD}$, Research Fellow, Institute of Social Sciences, University of Lisbon, Portugal. 'Graduate Student, University of London, UK. 
region in 2011. In their 2016 report, IDMC (2016) presents the staggering figure of nearly 4.8 million new displacements, showing the dramatic outcome of the increased violence and the rise of the terrorist group Daesh ${ }^{1}$ in the region; the MENA area is now home to half of the new internally displaced people (IDP) in the world.

In 2011, UNHCR (2011) reported a total of 42.5 million forcibly displaced people, including 15.2 million refugees of which 1.7 million was from the MENA region. Refugees in protracted situations continued to be part of these figures for the area, such as the 4.8 million Palestinian refugees registered with UNRWA $^{2}$. In 2015, the same agency reports 65.3 million forcibly displaced people, with 21.3 million refugees of which 5.4 million are from the MENA area (UNHCR 2015). Palestinian refugees are forcibly displaced again, while the Mediterranean saw an estimated million people fleeing to Europe by sea only in 2015 (MSF 2016). Numbers for both IDP and refugees have rapidly increased since 2011, yet the number of IDP has increased to $35 \%$, whereas the number of refugees augmented to $28 \%$ during the same period, showing that the world is not witnessing a refugee crisis and is rather facing a crisis of massive forced displacement.

Contrary to what might be the general perception, the majority of the Syrian refugees do not seek protection in Europe, and more than $90 \%$ have fled to the neighbouring countries: Turkey, Lebanon, Jordan, Egypt and Iraq. In this sense, the "refugee crisis" in Europe shows once again the failure of the EU's migration policies that become more dependent on the neighbouring countries, like Turkey, relying more on externalisation as a way to secure borders (Afailal 2016a).

In this sense, it is important to remember that Turkey has a long migratory history; its geostrategic position, together with conflicts and wars, have led to different forms of mobility from and to the country throughout many centuries. The arrival of the Sephardi ${ }^{3}$ in 1492, Hungarian and Polish refugees on the XIX century or the thousands of Circadian ${ }^{4}$ Muslims that fled wars, are among the important events that marked Turkish migratory history (Kirişci 2000). Also, the gradual contraction of the Ottoman Empire have laid foundation for the establishment of many displaced people of different origins in the new Turkey, as well as the migration of Bulgarians between 1923 and 1990, the asylum seekers throughout the history of modern Turkey, the "return" of the children and grandchildren of Turkish workers who migrated to European countries, are some of the profiles found in the migratory spectrum in Turkey, still in constant change and evolution, integrating new components of different origins.

For Turkey, border control has not been a priority as for the Schengen Europe. In fact, Turkey saw an important opening towards many countries with the development of trade relations, promoting the mobility of people and goods coming from places like Russia, former Soviet Union countries, Tunisia, Jordan,

\footnotetext{
'Abbreviation from "تنظيم الدولة الإسلامية في العراق و الثام" Arabic name given to the so called Islamic State, known as ISIL or ISIS.

${ }^{2}$ United Nations Relief and Works Agency for Palestine Refugees in the Near East.

${ }^{3}$ Sephardi descends from the Hispanic-Portuguese Jews that lived in the Iberian Peninsula until 1492

${ }^{4}$ Circadian are an ethnic group from the Northeast of the Caucasus
} 
Morocco and other Arab states. It also fostered a new visa system that allows nationals from over 50 countries to obtain entry visas at the Turkish borders (Tolay 2012).

The evolution of the Turkish policy towards securitization has been linked to the negotiation process related with the access to the European Union. Issues like the human rights situation in Turkey, the question of minorities and migration, start to have a strong weight in these negotiations (IHF 2006).

\section{The Securitization of Migratory Policies: Externalisation as a Result of Coloniality of Power}

Externalisation or outsourcing is a term from the economic sciences, also developed by other areas, especially by sociology and philosophy (González Navas 2012). In border practices, to externalize means to delocalize the limits of the control of a sovereign country through the implication and accountability of other countries. This practice assumes "migrations become part of the security agenda, implying that they are part of the foreign policy of the state, which is also something new" (González Navas 2012: 6). This reflection of González Navas takes us to a key concept of Zielonka (2007) regarding "fuzzy borders", that describes the EU borders as "blurry", resembling more like a fort against asylum seekers, with a logic of control that implies the creation of "semi-protectorates whose sovereignty is not denied but creatively constrained" (cited in Bialasiewicz 2012: 846).

Zielonka's reflection (2007) on "constrained sovereignty" guides us towards coloniality as a key concept that gives more insight into the complexity of this extra-territorialisation of sovereignty and control, provoking a reconfiguration of the power relations by Eurocentrism as a form of knowledge (Mignolo 2011) ${ }^{5}$. Quijano points out that coloniality "is one of the elements of construction of the world pattern of the capitalist power. Is based in the imposition of a racial/ethnic classification of the world population as a cornerstone of this power pattern and it operates in each of the plans, scopes and dimensions, material and subjective, of the everyday existence and at societal scale" (Walsh 2009: 28).

To understand the complexity of coloniality, we refer to the writings of Fanon, where he explains the relation between the "being" and the "non-being" (Fanon 1961). In the zone of the "being", subjects are considered to have a superior character, without oppression and living under privilege. While in the

\footnotetext{
${ }^{5}$ Quijano defines coloniality of power as "different from, although linked to colonialism. The latter refers strictly to a structure of domination/exploitation where control of the political authority, the production resources and the work of a specific population, is held by another authority of different identity whose headquarters are located in another territorial jurisdiction. But not always, and not necessarily, implies racist power relations. Colonialism is obviously older, whereas coloniality has proved to be, in the last 500 years, deeper and lasting than colonialism. But undoubtedly it was generated inside of it, and moreover, without this it would not have been imposed in the inter-subjectivity of the world in such a rooted and lasting way" (Grosfoguel et al, 2007:93).
} 
zone of the "non-being", subjects are considered inferior, facing oppression and enjoying no privilege.

Grosfoguel (2011) talks about global coloniality and remarks that this has no specific geographical space, but it has a particular characteristic: the inferiorization of the other. "The zone of the being and the no-being is not a specific geographical space but a positionality in the racial power relations that occurs at a global scale between centres and peripheries, but it also occurs at a national and local scale against different groups racially interiorized [...] There are zones of being and nobeing at a global scale between Westernized centres and non-Western peripheries" (2011: 99).

Lora (2012) adds that modernity as a Western construction in relation to the democratization processes of the former colonies has been limited to formal aspects without touching the profound bases of power's coloniality, an essential requirement to achieve complete democracy and a balanced cooperation. In this way, regional/external powers remain immune against national powers that have not been developed in an independent way from those regional/world forces.

Going back to Quijano we can conclude that a new form of coloniality emerges with the construction of the borders (in our case, externalized borders), as the principle of population classification is demonstrated (migrant vs. EU citizen) and also among countries (EU countries vs. countries to which control is externalised). In this sense, the security issue that justifies control and externalisation implies the construction of a stereotype about those migrants/ countries against which is necessary to preventively intervene before the arrival of the risk to the territory of the "being". The social classification of people that Quijano refers to in his writings becomes present, based on a series of characteristics that define people as risk sources from which protection is needed through border control measures (Quijano 1991; 1994). We can say that after all, the correlation between externalisation and control is effective to regulate power relations, as well as to introduce a new form of coloniality that coexists with the evolution of power relations at a worldwide scale.

\section{Managing the Undesirables: The Making of the EU - Turkey Agreement}

Given its geographic position, the proximity to the Middle East and to the former Soviet Union countries, Turkey was influenced by a region marked by an exponential increase in the number of conflicts, besides a high degree of violence. In the last decades, the armed conflict of Northwest Iran, the on-going war in Iraq, the one in Afghanistan, the situation in Palestine and the most recent war in Syria, have been some of the conflicts with the highest influence on the internal and foreign policy of the country.

Throughout these years, Turkey has developed a significant experience in asylum management, keeping refugees in a permanent situation of temporary protection. Despite the critics on its geographic reservation in the 1951 Refugee Convention, which restricts access to refugee status to persons from 
Europe $^{6}$, Turkey has insisted on keeping this in force, being the only country that effectively implements a difference between European and non-European refugees. The Syrian conflict marked a before-and-after in Turkish immigration policies, as the country now hosts the largest number of refugees in the world.

Following the unprecedented numbers of forcibly displaced people crossing and drowning in the Mediterranean in 2015 (IOM 2015), the EU held a special meeting in April that year to increase the financial resources of the Frontex-led operations. The role of the EU is clear then and in future tragedies that followed: increased coordination with non-EU countries "preventing illegal migration flows" with a special mention for Turkey in view of the situation in Syria and Iraq, assuming civilians from these countries are migrants and not de facto refugees (Council of Europe 1976), implying that reaching Europe through the Mediterranean they are doing it illegally, despite the lack of legal and safe procedures to respond to this massive forced displacement. The statement of the meeting adds also that "while respecting the right to seek asylum, [the EU will] set up a new return programme for the rapid return of illegal migrants from frontline Member States, coordinated by FRONTEX' (European Council 2015: 1).

In following months, a joint action plan with Turkey was established to address the root causes of the massive influx of Syrians and support them under Turkey's temporary protection regime. Two years before the EU emergency meeting, Turkey approved the Law on Foreigners and International Protection (Ministry of Interior of the Republic of Turkey 2013a), providing temporary protection to foreigners who were forced to leave their countries and unable to return, arriving at or crossing Turkey's borders in masses to seek urgent and temporary protection and whose international protection requests cannot be taken under individual assessment. By October 2015, the time of this joint plan with the EU, Turkey had already spent more than $\$ 6$ billion assisting 2 million refugees: 1.7 million Syrians and 300,000 Iraqis.

Adapting for several years to the emergencies in the region and sharing a 900kilometres border with war torn Syria, Turkey would need more than financial aid from Europe to be attracted to step up the coordination with the EU and indeed Europe confirmed that "accession negotiations remain the cornerstone of EUTurkey relations" (European Commission 2015: 1) and that the joint "plan builds on and is consistent with commitments taken by Turkey and the EU in other contexts notably the Visa Liberalisation Dialogue" (European Commission 2015: 1).

Analysing the joint action plan and keeping in mind the commitment of both parties to address this crisis in a spirit of burden sharing, Europe's commitments focused on increasing financial resources to Turkey and other refugee-host countries of the region (Jordan, Iraq and Lebanon), reinforcing the Turkish Coast Guard and surveillance capacity including joint return operations and increasing financial assistance to develop a well-functioning asylum, migration, visa and integrated border management system in Turkey, in line with the EU-Turkey visa dialogue. Turkey committed to continue the already existing efforts it initiated

\footnotetext{
${ }^{6}$ Turkey maintains the geographical scope of the original text of the 1951 Refugee Convention.
} 
long before Europe's request, reinforcing its maritime interception capacity, increasing coordination with neighbouring countries to prevent irregular migration, readmitting irregular migrants who are not in need of international protection (regardless of how hard is to ensure individual assessments will take place for these numbers of forcibly displaced people), intensifying cooperation with Frontex and ensuring asylum procedures are completed to quickly grant refugee status.

The burden was not equally distributed when it comes to provision of protection and humanitarian assistance. Despite affirming that "human dignity is at the core of our common endeavor", Europe continued to give priority to applying problem-oriented policing to an emergency humanitarian situation at its doorstep, treating the forcibly displaced as irregular/illegal migrants that need to be stopped and prevented from entering the fortress.

In March 2016, an agreement was concluded between Turkey and the EU on refugee issues, attracting legal and political controversy. Given the limitations of this article, the entire text will not be analysed but some of the main polemic points will be highlighted, based on Professor Steve Peers' analysis from the University of Essex ${ }^{7}$ :

For a document presented to the public as a response to the refugee crisis, the title speaks instead of "readmission of persons residing without authorisation, [...] to combat illegal immigration more effectively" (European Union 2015: 1). The objective is too safely and orderly return people who no longer fulfil the requirements to enter or stay in Europe or Turkey.

No definition is provided for asylum seekers or refugees in Article 1 of the agreement; instead, the document chooses the term "person residing without authorisation", an ambiguous definition that might lead to arbitrary practices on the ground. Turkey shall readmit people defined under this and other criteria within a period of three working days after the requesting EU member state request it, regardless of the will of the person to be readmitted.

Readmission will not apply if the third country national or stateless person has only been in airside transit via an international airport of Turkey, holds a visa or residence permit for a member state or for Turkey with a longer period of validity or if the person enjoys a free access visa to the territory of the requesting member state.

Noting that all the forcibly displaced people crossing the Mediterranean lack the financial resources or the means that enable them to obtain a European visa and travel there safely by plane, noting that no humanitarian visa system is in place to allow them to reach Europe safely and then seek asylum and noting that they do not enjoy free access visa to Europe (hence why they risk their lives in the sea), this agreement does not tackle the protection and humanitarian needs of the forcibly displaced equally with Turkey.

As provided for in the agreement, efforts must be made to return the person directly to his/her country of origin and persons apprehended by the requesting state in the border region after having entered illegally and directly to its territory, will be readmitted through an accelerated procedure, raising concerns on potential "hot returns", a practice often observed in the Southern border of

\footnotetext{
${ }^{7}$ Steve Peers is a Professor of EU and Human Rights Law at the University of Essex.
} 
Melilla, involving the Spanish and Moroccan governments (ECCHR 2015). It is also important to highlight that collective expulsions are banned in the EU Charter and the ECHR, as well as in the EU asylum legislation.

For every Syrian returned to Turkey from Greece, another will be resettled from Turkey to Europe; this refugee exchange not only fails to address the crisis of forcibly displaced people in the Mediterranean, but also contradicts the ethics of protection and humanitarian assistance. Only if resettlement to Europe is done in a very quick and efficient manner, this might deter people from risking their lives in the sea. However, out of the 160,000-people suggested for resettlement and relocation to Europe in September 2015, respectively of the latest targets set to relocate 20,000 and to resettle 22,504 by mid-May, only 1,500 were relocated and 6,321 were resettled (European Commission 2016). Only $0.15 \%$ of the entire population in question were offered legal and safe migration channels. Europe fails to comply with its part of the deal.

The visa liberation roadmap to lift visa requirements for Turkish citizens at the latest by the end of June 2016 finds its place in the readmission agreement, as any Turkish citizen overstaying beyond the 3-month visa period will be sent back to Turkey. This did not only happen in the established timeframe but also Ankara suspended temporarily the agreement (Daily Sabah 2016) at the beginning of June 2016 due to disagreements in anti-terrorism aspects that are required to move forward with the visa liberalization for Turkish nationals.

\section{Conclusions}

Throughout this research, we conclude that studying the Turkish case allows a deep analysis of the growing EU influence in the internal migration policies of its neighbouring countries, through the process of border externalization, with the objective of controlling access to "fortress Europe". In this sense, control strategies are proposed with the goal of "stopping undesired subjects before they arrive to the physical border, denying rights that they would have after entering the national territory" (Jerrems 2009: 15). This practice implies a mandatory reflection on the external dependence on actions that occur outside the space of the national sovereignty of the states (Tabernero 2013) as a way to extra-territorialize control and sovereignty, added to a clear exercise of coloniality.

Readmission from Europe to Turkey will be the likely outcome rather than the opposite, as most of the major forced displacement passes through Turkey, a safe country of return for Europe. The burden is not equally distributed between Turkey and Europe once again.

Another controversial issue around this agreement is whether Turkey is a safe third country or not, as the treatment in Turkey must match EU rules, ensuring the people concerned does not have their life or freedom threatened on the same grounds established in the 1951 Refugee Convention, there must be "no risk of serious harm" (death penalty, torture, civilian risk in wartime) and the nonrefoulement rule will be respected. Finally, the possibility to request refugee status and to receive protection must be available and in this particular aspect, 
concerns are raised as Turkey applies restrictions to non-European refugees, offering temporary protection for them only. Reports from different organizations suggest that all these rules are not always respected.

The establishment of a new immigration policy and a new specific law on immigration and asylum in Turkey have been seen as an important opportunity to make progress with respect to migrant rights. However, some aspects of the new law, especially regarding the diverse reasons that justify deportations and the increase of detention periods, constitute important restrictive legislative measures and reflect a clear orientation towards the securitization of migration (Afailal 2016b).

Finally, the reference in the EU-Turkey agreement to establish a safe zone inside Syria for IDP and refugees to reside near the Turkish border remains a plan and raises questions regarding how the EU would ensure that Turkey does not send people beyond this safe area. In this sense, it's important to remember that at least ten decisions by the Administrative Appeals Committee of Lesbos were published in which it is asserted that Turkey is no "safe third country" for Syrian refugees (Pro Asyl 2016).

\section{References}

Afailal H (2016a) Las migraciones inesperadas: Marruecos y Turquía entre diversidad y seguridad [Unexpected migrations: Morocco and Turkey between diversity and security]. PhD thesis.Spain: Rovira i Virgili University.

Afailal H (2016b) Euro-Mediterranean Relations in the Field of Migration Management: Contrasting Morocco and Turkey as Case Studies. In N Ribas Mateos (ed), Migration, Motilities and the Arab Spring.UK: Edward Elgar Publishing.

Bialasiewicz L (2012) Off-shoring and Out-sourcing the Borders of Europe: Libya and EU Border Work in the Mediterranean. Geopolitics 17 (4): 843-866.

Parliamentary Assembly (1976) Council of Europe Recommendation 773: Situation of de facto Refugees. Retrieved from https://bit.ly/2lIdtOp. [Accessed 04 April 2018].

Daily Sabah (2016) Ankara halts Readmission Agreement with EU, disagrees on antiterrorism laws. Retrieved from https://bit.ly/2Kk3RIn. [Accessed 04 April 2018].

ECCHR(2015) Spanish-Moroccan land border in Melilla - a lawless zone of automatic expulsions. Retrieved from https://bit.ly/2KuRetk. [Accessed 02 April 2018].

European Commission (2015) EU-Turkey joint action plan. Retrieved from https://bit. ly/1QLn5m0. [Accessed 02 April 2018].

European Commission (2016) Third report on relocation and resettlement,COM 360 final, Brussels.Retrieved from https://bit.ly/2IB3fbA. [Accessed 04 March 2018].

European Council (2015) Statement of the special meeting of the European Council. Retrieved from https://bit.ly/2tL1DaL. [Accessed 03 April 2018].

Fanon F (1961) Los condenados de la tierra [The condemned of the earth]. Paris: Maspero.

González NA (2012) Estudios críticos de seguridad, migraciones internacionales y ayuda al desarrollo

XI Congreso Política en tiempos de incertidumbre, Sevilla [Critical security studies, international migration and development aid XI Political Congress in times of uncertainty, Seville]. Retrieved from https://bit.ly/2MAVSmX. [Accessed 03 December 2017]. 
Grosfoguel R (2011) Decolonizing Post-Colonial Studies and Paradigms of PoliticalEconomy: Transmodernity, Decolonial Thinking, and Global Coloniality. Journal of Peripheral Cultural Production of the Luso-Hispanic World, School of Social Sciences, Humanities, and Arts, UC Merced. Retrieved from https://bit.ly/2tQ2RjZ. [Accessed 03 December 2017].

IDMC (2011) Global Overview Report. Retrieved from https://bit.ly/2KwfWpO.

IDMC (2016) Global Report on Internal Displacement. Retrieved from https://bit.ly/23 $\mathrm{B} 12 \mathrm{mq}$.

IHF (2006) Turkey: A Minority Policy of Systematic Negation. Retrieved from https://bit. ly/2yT4LGf. [Accessed 26 October 2017].

IOM (2015) IOM Counts 3,771 Migrant Fatalities in Mediterranean. Retrieved from https://bit.ly/1PHKmSZ. [Accessed 05 July 2017].

Jerrems A (2009) An introduction to critical border studies. In Border Politics: The Limits of Sovereign Power 10(1). Edinburgh: Edinburgh University Press.

Kirişci K (2000) Disaggregating Turkish citizenship and immigration practices. Middle Eastern Studies 36(3).

Ministry of Interior of the Republic of Turkey (2013a) Law on Foreigners and International Protection. Retrieved from: https://bit.ly/1AvorGQ. [Accessed 01 July 2016].

Mignolo WD (2011) The Darker Side of Western Modernity, Global Futures, Decolonial Options. USA: Duke University Press.

MSF (2016) Obstacle course to Europe: A policy-made humanitarian crisis at EU borders. Official Journal of the European Union. Retrieved from https://bit.ly/2yUlOrF. [Accessed 04 April 2018].

Presidency of the Republic of Turkey (2005) Turkey and all kindred Siblings As such, it is next to the Uighur Turks in China. Retrieved from https://bit.ly/2KuKLP2 [Accessed 01 July 2017].

Pro Asyl (2016) Press release, “Appeals Committee on Lesbos stops deportations to Turkey”. Retrieved from https://bit.ly/22zLu0X. [Accessed 06 July 2017].

Quijano A (1991) Colonialidad y Modernidad/Racionalidad [Coloniality and Modernity / Rationality]. En Peru Indigena 13(29): 11-20.

Quijano A (1994) Colonialité du Pouvoir et Democratie en Amerique Latine [ Coloniality of Power and Democracy in Latin America]. In Future Anterieur: Amérique Latine, Democratie Et Exclusion. Le Harmattan.

Peers S (2016) The draft EU/Turkey deal on migration and refugees: is it legal? Retrieved from https://bit.ly/2KkH9Qc. [Accessed 04 July 2017].

Tabernero MC (2013) Security and border. The externalization of the border and the securitizing responsibility. Communication intended for presentation in the working group 'Critical Security Studies: disputes and theoretical proposals' of the XI Congress of the AECPA. Autonomous University of Madrid.

UNHCR (2011) Global Trends report 2011. Retrieved from https://bit.ly/2MAyPs7.

UNHCR (2015) Global Trends, Forced Displacement in 2015. Retrieved from https://bit. ly/2aa1vbu.

Walsh C (2009) Interculturalidad, Estado, Sociedad: Luchas (de) coloniales de nuestra época. [Interculturality, State, Society: Struggles (of) colonial of our time]. Simon Bolivar Andean University.

Zielonka J (2007) Europe as Empire: The Nature of the Enlarged European Union. Oxford: Oxford University Press. 
